\title{
Evaluation Framework With CIPOO Model For Industrial Internship in Light Vehicle Engineering (TKR) Major
}

\author{
Yustin Setiy a Widoretno \\ State University of Malang \\ Malang, Indonesia \\ Email: yustin_setiyo@rocketmail.com
}

\begin{abstract}
The review of the literature shows that conceptual evaluation program is numerous and evolves over the time, which can be used as the guideline for the researcher. Although it is not a new model, CIPOO evaluation model which is introduced in this artide can be useful for guiding the plan, implementation and evaluation of industrial internship program. Through this review of the literature, $S$ tufflebeam's evaluation model named CIPOO (Context, Input, Output, and Outcome) is recommended for a systematic and comprehensive framework that can provide feedback and the assessment of industrial internship program, as well as its implementation and continuous improvement. The CIPOO model consists of five dimensions namely Context, Input, Process, Output and Outcome, which is: a) Context is seen from the policy and environment of the program; b) Input is seen from the system of students' recruitment, human resources, curriculum, infrastructure, and funding; c) Process is taken from the program's old system, pre-program, also the process and the ending of the program; d) Output which has been achieved is considered from the benefit of the industrial internship program (internship's score and summative test) and skill certification; and e) Outcome is considered from the period of time since the students' graduation until their first job, and its relevance. This article gives the representation of industrial internship's implementation and evaluation.
\end{abstract}

\section{Keywords-evaluation, industrial internship, CIPOO}

\section{INTRODUCTION}

Since the implementation of ASEAN Economic Community (AEC) in 2016, the competition of employment market in ASEAN is getting higher as the result of many foreign workers who enter Indonesia. The companies hire more foreign workers because they consider that Indonesia workers have lower skills than foreign workers. Therefore, the new government under Joko Widodo and Jusuf Kalla established the sixth nawacita to increase people's productivity and competitiveness in the global market (Kompilasi Artikel Kemdikbud, 2017:46).

The workers from several Asian countries start coming to Indonesia. As a result, Indonesia must prepare qualified human resources to face AEC. According to Latief (2016), Indonesian human resources, especially the youth, must have a proper preparation to compete in global market, especially in this AEC. It needs a synergy between the community and the government in the development of human resources in Indonesia.
Based on the survey result from Central Bureau of Statistics (BPS) as of August 2016, there are 7,24 million from 182,99 million of Indonesian workers are unemployment. The highest rate of the unemployment comes from the Vocational High School (VHS) graduates for 11,24\% followed by Senior High School for 9,55\%, Junior High School for 7,15\%, Diploma for $6,14 \%$ and bachelor degree for $5,65 \%$. The lowest rate is found for Primary School's graduates and lower with $3,04 \%$. On the contrary of the policy for VHS' ratio since 2005, the schools even give the highest unemployment rate which shows the unclarity of the education's direction (Jawa Pos newspaper Link and Match Pendidikan Vokasi, January 3, 2017)

The biggest challenge for the government to create competent human resources which are suitable for the needs of the labor market is the involve ment of the business world or industries (DU/DI). The factor that causes a high rate of unemployment for VHS graduates is the irrelevancy between the competence of the school graduates designed by the government and that is required by the industries (Co mpilation of Kemdikbud articles, 2017:67).

In this 21 st century, education becomes more significant to guarantee that the students have learning and innovation skill, the skill to use technology and media of information, also can cooperate and survive with their living and working skills (Trilling and Fadel, 2009:49). Also, one of VHS' goals is to have graduates who work independently or can be interpreted as becoming an entrepreneur and creating job opportunity for others. Mukhadis (2013:8) stated that based on substantial side and orientation of result's demand, vocational education functions as a means to facilitate the development of the students' individual and group skills to take roles as the innovator or job creator.

Since 2015, the government has launched the policy of 70:30 ratio by the expectation that $70 \%$ of all students who study in VHS would increase. This policy was intended to reduce the number of youth's unemployment by giving jobspecific skills for vocational students. In fact, the education in VHS cannot give a clear advantage to the graduates in the work field. The success of increasing the number of high educated workers has not been followed by the quality of education. Without the clear improvement of labor condition, today's expansion of VHS will be a costly process for both 
government and parents (Newhouse, David and Daniel Suryadarma, 2009).

The main mission of VHS is to prepare the students as prospective workers who are ready to enter the work field. VHS is required to provide the students with skills and professional attitude in the fields. In accordance with the goals of VHS in the curriculum (Dikmenjur, 2008) to create the graduates who (1) enter the work field and enhance the professionalism, (2) are able to choose the carrier, have competence, and have self-development ability, (3) become the middle-class workers who can fulfill the needs of current and future's business world and industries (DU/DI), and (4) become productive, adaptive, and creative workers.

The internship program in VHS has some names, which are Pendidikan Sistem Ganda (PSG), Praktik Kerja Industri (Prakerin),and Praktek Pengalaman Lapangan (PKL). From those names, the commonly used name is Pendidikan Sistem Ganda (PSG) or in English is Dual System Education, because it is the first name given for internship program and the mostly used name. The aims of internship are: 1) create workers who have professional skills, 2) strengthen link and match between school and industries, 3 ) improve the efficiency of education process and work training, 4) give recognition and appreciation to work experience as a part of education process (Sonhadji, 2014:165).

Prakerin, or industrial internship, is one of the school programs' implementation to develop the students' knowledge and enhance their experience to get ready to work, and it is a part of PSG. The industrial internship is a compulsory course for VHS students which is a part of PSG. In the technical guidance of PSG in VHS, it is mentioned that industrial internship is a productive skill that takes places in industries and contains learning activity which teaches production and service works (Kemendiknas, 1997).

The industrial internship program will help the students to strengthen learning evaluation which is obtained at school as well as give the students real experiences in accordance with their major in VHS. Weiman (Made Wena, 1996:22) stated that "the didactic of path vocational training is the mastery of life at work" and it happens through an industrial internship. Without doing this systematic program, vocational schools cannot provide the graduates with optimum skills. In addition to that, he also explained that the concept of "linking the school with life" has to be seriously applied in the internship of vocational education.

The industrial internship leads to the professional achievement which is in line with the work demands in the work field. This educational program can be achieved if there is a cooperation between educational institution and industries, since the industries know well about what standards which are required in the work field. The cooperation covers the planning, implementation, evaluation, and the placement of graduates which are all summarized in an industrial internship. Although the internship is supposed to be an ideal time and place for students to gain knowledge in the work field, the fact shows that may students are signed in random places and the teachers only monitor them (Putu Agus Mayuni, Ni Wayan Sukerti, 2016: 85).
The importance of program evaluation in improving the quality of vocational education is to fulfill the demand of welleducated workers to improve the minimum standard of vocational education; thus, the program evaluation needs to be made. In order to minimize the percentage of the unemployment graduates, on the way that can be done is to evaluate the industrial internship program so that the evaluators can find the weak point to be improved or revised as well as to know the effectivity of the next program. The evaluation is important to know the continuation of the program and the quality control.

Through this review of the literature, Stufflebeam's evaluation model Context, Input, Procces, Output, and Outcome (CIPOO) is recommended as the systematic and comprehensive framework to give feedback and assessment of the effectiveness of industrial internship program. The subject of the research in this article was the major of Light Vehicle Engineering (TKR) program in SMK Negeri 1 Sidoarjo.

\section{OBJECTIVES}

The objectives of this research were to determine the dimension of:

1. The context in the industrial internship at Light Vehicle Engineering (TKR) program in SMK Negeri 1 Sidoarjo.

2. Input in an industrial internship at Light Vehicle Engineering (TKR) program in SMK Negeri 1 Sidoarjo which was considered from the system of students' recruitment, human resources, curriculum, infrastructure, and funding.

3. Process of the industrial internship program at Light Vehicle Engineering (TKR) program in SMK Negeri 1 Sidoarjo fro $m$ the program's old system, pre-program, also the process and the ending of the program.

4. Output which has been achieved is considered from the benefit of the industrial internship program of Light Vehicle Engineering (TKR) program in SMK Negeri 1 Sidoarjo (score of internship and summative test) and skill certification; and e) Outcome is considered from the period of time since the students' graduation until their first job, and the relevance of the students' job.

\section{DISCUSSION}

Evaluation is a process to provide the information which is used as consideration to determine the worth and merit of the goal which is achieved, design, implementation, and the effect to help to make a decision, help in responsibility, as well as increase the understanding of the phenomenon (Widoyoko, 2012:4). According to Joseph S. Wholey, et al. (2010:5-6), evaluation program is the application of the systematic method to answer questions about the implementation and result of a program. This possibly includes the observation of ongoing program and one-way study of the process or effect of the program.

Stufflebeam (2003:2) explained that CIPP model is a comprehensive framework to guide formative and summative evaluation. The four components in Stufflebeam's evaluation 
concept plays a significant role in the planning, implementation, and assessment of a project. Specifically, components of evaluation from context, input, process, and evaluation of the product can help identifying the learning needs of service providers and community needs (Zhang, Guili, at al., 2011:59). When the evaluation is used effectively, it supports the program's improvement, knowledge, and accountability (United Nations Development Programme, 2009:127).

Azma Hasan, et al. (2015) stated that the researchers identify the curriculum based on the context of dimension, input, process, and product in the diploma of Mechatronic Engineering in a polytechnic towards the needs of the industries in Malaysia. The CIPP model from Stufflebeam has been utilized and planned not only as the evidence of certain decision but also as the guideline to create a program.

CIPP evaluation is very useful to guide the planning, implementation, and assessment of a service-learning program which covers: (1) exploration of the root of CIPP evaluation model theory and its application, (2) illustration of the four components, (3) analysis of each component's role in the success of service-learning program, and (4) discussion of the process of the model's effectivity in managing the standard of service-learning program for quality practice.

Through this review of the literature, Stufflebeam' Context, Input, Procces, Output, dan Outcome (CIPOO) evaluation model is recommended as the systematic and comprehensive framework which give feedback and give an effective assessment of industrial internship program. Stufflebeam dan Coryn (2014:321) explained that this evaluation process is related to the program's implementation. There are numbers of question which must be answered through the evaluation process such as does the implementation works as it is planned and what to be improved in its implementation. Thus, the implementation of the program can be monitored and even improved.

\section{CIPP Evaluation Model}

CIPP evaluation model was developed by Daniel Stufflebeam and his team in 1967 at Ohio State University. The theory defines evaluation as the process of delineating, obtaining, and providing information for assessing the alternatives of decision making. CIPP is the abbreviation of (1) Context evaluation, (2) Input evaluation, (3) Process evaluation, and (4) Product evaluation.

This model is now completed by the addition of $\mathrm{O}$ component which refers to the outcome, so that it becomes CIPOO model. The CIPP evaluation model ends in measuring output, while CIPOO model is extended until the implementation of the product.

Stufflebeam (2014:392) stated that "context evaluation to serve planning decision". It means an evaluator must be thorough and definite in comprehending the evaluation context which is related to plan the decision, identify the needs, and formulate the objectives of the program. Furthermore, Stufflebeam and Coryn (2014:319) added that the input evaluation is structuring decision. Any influence on the process of evaluation must be prepared correctly. Input evaluation is for identifying and assessing the capability of materials, tools, human resources and funding, in order to run the chosen program (Mulyatiningsih, 2011:129). While process evaluation is to serve the implementation of decision (Stufflebeam and Coryn, 2014:321). This process evaluation is related to the implementation of a program.

The objectives of product evaluation are to measure, define, and assess the achievement of a company (Madaus dkk, 2002: 297). The main goal is to confirm how far the evaluation has evaluated the conformity between the needs and the proper acceptance. The feedback for the achievement is important for both during the activities cycle and the conclusion. In addition to that, the product evaluation must be spread how far the program has fulfilled the needs of the group for the service aspect.

\section{The Implementasi of CIPOO Evaluation Model}

The researcher suggests the application of matrix by using some sources of data, in regards to the industrial internship program as well as its relevance. The five components with their indicators and standards are explained as follows:

\begin{tabular}{|c|c|c|c|}
\hline No. & $\begin{array}{l}\text { Component } \\
\text { of } \\
\text { CIPOO }\end{array}$ & Indicator & Standard \\
\hline \multirow[t]{7}{*}{1} & \multirow[t]{7}{*}{ Context } & $\begin{array}{l}\text { Policy } \\
\text { Notes: } \\
\text { (Permendikbud } \\
\text { No.60 in } 2014 \text { about } \\
\text { Curriculum } 2013 \text { of } \\
\text { SMK/MAK) } \\
\end{array}$ & $\begin{array}{l}\text { Has objectives, programs, } \\
\text { benefit and rule }\end{array}$ \\
\hline & & \multirow{2}{*}{$\begin{array}{l}\text { Environment } \\
\text { Notes: Practicum } \\
\text { guideline for an } \\
\text { industrial internship } \\
\text { of Curriculum } 2013 \\
\text { for Vocational High } \\
\text { School }\end{array}$} & $\begin{array}{l}\text { a. Mapping of the industries } \\
\text { which are suitable for the } \\
\text { students' needs }\end{array}$ \\
\hline & & & $\begin{array}{l}\text { b. Clear description of } \\
\text { competences }\end{array}$ \\
\hline & & $\begin{array}{l}\text { Student's } \\
\text { Recruitment }\end{array}$ & $\begin{array}{l}\text { c. Mapping of the industries } \\
\text { which is suit able for the } \\
\text { students' needs }\end{array}$ \\
\hline & & Curriculum & $\begin{array}{l}\text { d. The existence of } \\
\text { structured and clear } \\
\text { material/skill/ competence }\end{array}$ \\
\hline & & \multirow[t]{2}{*}{ Supervisor (teacher) } & $\begin{array}{l}\text { e. Minimum with Bachelor } \\
\text { degree in relevant major }\end{array}$ \\
\hline & & & $\begin{array}{l}\text { f. Consistent guidance and } \\
\text { consultation }\end{array}$ \\
\hline \multirow[t]{3}{*}{2} & \multirow[t]{3}{*}{ Input } & $\begin{array}{l}\text { Infrastructure on the } \\
\text { field }\end{array}$ & $\begin{array}{l}\text { a. Give guidance to the } \\
\text { students in the industry } \\
\text { b. Give suit able job } \\
\text { description based on } \\
\text { students' major }\end{array}$ \\
\hline & & Funding & $\begin{array}{l}\text { c. Transparency of the } \\
\text { funding for industrial } \\
\text { internship }\end{array}$ \\
\hline & & $\begin{array}{l}\text { Infrastructure } \\
\text { Notes: The } \\
\text { availability of } \\
\text { classroom, learning } \\
\text { tools, workshop, or } \\
\text { laboratory }\end{array}$ & $\begin{array}{l}\text { d. The availability of } \\
\text { supporting infrastructure } \\
\text { from the school and } \\
\text { industry. }\end{array}$ \\
\hline
\end{tabular}




\begin{tabular}{|c|c|c|c|}
\hline \multirow[t]{4}{*}{3} & \multirow[t]{4}{*}{ Process } & Duration & $\begin{array}{l}\text { a. In line with the } \\
\text { curriculum of VHS ( } 4 \\
\text { years) which is } 1 \text { year of } \\
\text { industrial internship }\end{array}$ \\
\hline & & $\begin{array}{l}\text { Process } \\
\text { a. Pre-program }\end{array}$ & $\begin{array}{l}\text { a. Industrial internship's } \\
\text { committee } \\
\text { b. Mapping of the industries } \\
\text { where the internship takes } \\
\text { place } \\
\text { c. Cooperation between } \\
\text { institution } \\
\text { d. Give socialization and } \\
\text { preparation program for the } \\
\text { students }\end{array}$ \\
\hline & & b. Implementation & $\begin{array}{l}\text { a. Ceremony to transfer the } \\
\text { students to industry } \\
\text { b. The job description is } \\
\text { suitable with students' } \\
\text { major } \\
\text { c. A continuous guidance } \\
\text { from the instructor } \\
\text { d. The availability of } \\
\text { working tools }\end{array}$ \\
\hline & & c. Assessment & $\begin{array}{l}\text { a. Daily journal and final } \\
\text { report of industrial } \\
\text { internship } \\
\text { b. The assessment from the } \\
\text { industry } \\
\text { c. The assessment from } \\
\text { school }\end{array}$ \\
\hline 4 & Output & $\begin{array}{l}\text { The test's score/ } \\
\text { certificate of skill }\end{array}$ & $\begin{array}{l}\text { a. Pass the internship with } \\
\text { certificate } \\
\text { b. The score is above the } \\
\text { minimum standard of } \\
\text { graduates }\end{array}$ \\
\hline 5 & Outcome & $\begin{array}{l}\text { a. The waiting } \\
\text { period until having } \\
\text { the first job } \\
\text { b. The relevance } \\
\text { with the major }\end{array}$ & $\begin{array}{l}\text { a. Finding the job quickly } \\
\text { b. The graduates' jobs are in } \\
\text { line with their major }\end{array}$ \\
\hline
\end{tabular}

\section{CONCLUSION}

The review of the literature shows that there is numerous conceptual model for program evaluation and they have been evolved over the time. This review of literature can be used as a guideline for the researcher. Although CIPOO is not a new evaluation model, it still applicable and useful for guiding planning, implementation, and assessment for an industrial internship. The CIPOO model consists of five dimensions namely Context, Input, Process, Output and Outcome, which is: a) Context is seen from the policy and environment of the program; b) Input is seen from the system of students' recruitment, human resources, curriculum, infrastructure, and funding; c) Process is taken from the program's old system, pre-program, also the process and the ending of the program; d) Output which has been achieved is considered from the benefit of the industrial internship program (score of internship and summative test) and skill certification; and e) Outcome is considered from the period of time since the students' graduation until their first job, and its relevance with their major. This article gives the representation of industrial internship's implementation and evaluation.

\section{REFERENCES}

[1] Dikmenjur. 2008. Prakerin Sebagai Bahan dari Penelitian Sistem Ganda. Jakarta:Depdikbud.

[2] Hasan, Azman, et al. 2015. A Conceptual Framework for Mechatronics Curriculum Using Stufflebeam CIPP Evaluation Model. ProcediaSocial and Behavioral Sciences Volume.195 p.844 - 849. Diakses pada tanggal 20 Mei 2017.

[3] Jawa Pos, Newspaper (2017 Jan 03). Link and Match Pendidikan Vokasi. P.35

[4] Latief, 2016. Anak Muda Butuh "Entrepreneur Skill” untuk menghadapi MEA. (Online),(http://edukasi.kompas.com/read/2016/03/07/13220051/Anak .Muda.Butuh.Entrepreneur.Skill.untuk.Hadapi.MEA). Diakses tanggal 05 Juni 2017.

[5] Keputusan Menteri Nomor. 323/U/1997. Praktik Kerja Industri SMK. Jakarta: Pusat Data dan Informasi Pendidikan, Balitbang-Depdiknas

[6] Madaus, George F., Daniel L. Stufflebeam, dan Thomas Kellaghan. 2002. Evaluation Models Viewpoints on Educational and Human Services Evaluation Second Edition. Dordrecht: Kluwer-Nijhoff Publishing.

[7] Mukhadis, A. 2013. Evaluasi Program Pembelajaran Bidang Teknologi. Malang: Bayumedia Publishing.

[8] Mulyatiningsih, Endang. 2011. Metode Penelitian Terapan Bidang Pendidikan. Bandung: CV. Alfabeta.

[9] Newhouse, David Locke and Daniel Surya darma. 2009. The Value of vocational Education: High School Type and Labor Market Outcomes in Indonesia. World Bank Policy Research W orking Paper 5035.

[10] Putu Agus Mayuni, Ni Wayan Sukerti. 2016. Optimalisasi Peran Duni Usaha dan Industri dalam Pengembangan Profesionalisme Guru SMK Secara Berkelanjutan. Prosiding Seminar Nasional Asosiasi Pendidikan Teknologi dan Kejuruan Indonesia-APTEKINDO, 2016:85)

[11] Stufflebeam, D.L. (2003) The CIPP model for evaluation: An update, a review of the model's development, a checklist to guide implementation. Paper presented at the 2003 Annual Conference of the Oregon Program Evaluators Network (OPEN) Portland, Oregon. $\begin{array}{lllll}\text { Diakses pada tanggal } 10 & \text { Juni } & 2017\end{array}$ http://www.wmich.edu/evalctr/cippmodel.

[12] Stufflebeam, D.L. and Coryn Chris L.S. 2014. Evaluation, Theory, Models and Application. 2nd Edition. San Fransisco: Jossey-Bass.

[13] Trilling and Fadel. 2009. 21st Century Skills: Learning for life in our times. USA: Jossey-Bass.

[14] United Nations Development Programme (UNDP). (2006). Handbook on Monitoring and Evaluating for Results. New York: Author.

[15] Wena, Made. 1996. Pemanfaatan Industri Sebagai Sumber Belajar dalam Pendidikan Sistem Ganda. Jurnal Pendidikan dan Kebudayaan. Th. III, No.010 September.

[16] Widoyoko. 2012. Evaluasi Program Pembelajaran. Yogyakarta: Pustaka Belajar.

[17] Wholey, S. Joseph, et al. 2010. Handbook of Practical Program Evaluation. Third Edition. San Fransisco: Jossey-Bass.

[18] Zhang, Guili, et al. 2011. Using the Context, Input, Process, and Product Evaluation Model (CIPP) as a Comprehensive Framework to Guide the Planning, Implementation, and Assessment of Servicelearning Programs. Journal of Higher Education Outreach and Engagement. Diakses pada tanggal 10 Juni 2017. 